\title{
Clinico-Haematological Profile of Haemophilia in Patients Attending Gandhi Medical College and Associated Hamidia Hospital, Bhopal
}

\author{
Rajendra Kumar Nigam¹, Praveen Sharma², Rajni Choudhary³, Reeni Malik ${ }^{4}$ \\ ${ }^{1}$ Department of Pathology, Gandhi Medical College, Bhopal, Madhya Pradesh, India. ${ }^{2}$ Department of Pathology, Gandhi \\ Medical College, Bhopal, Madhya Pradesh, India. ${ }^{3}$ Department of Pathology, Gandhi Medical College, Bhopal, Madhya \\ Pradesh, India. ${ }^{4}$ Department of Pathology, Gandhi Medical College, Bhopal, Madhya Pradesh, India.
}

\section{ABSTRACT}

\section{BACKGROUND}

Haemophilia A and haemophilia B are the commonest form of haemophilia encountered and they result from a defect in Factor VIII and Factor IX gene respectively. This hinders the process of haemostasis and predisposing haemophiliacs to spontaneous or post traumatic bleeding. We wanted to study the clinico-haematological profile of patients with haemophilia.

\section{METHODS}

This observational study was conducted in Gandhi Medical College and Associated Hamidia Hospital, Bhopal, during the period of March 2017 to June 2018. After clinical evaluation, patients were subjected to a battery of coagulation tests (Bleeding Time, Prothrombin Time, Activated Partial Thromboplastin Time, Correction Studies and whenever possible, Specific Coagulation Factor Assay). The results were analysed.

\section{RESULTS}

During the study period, 100 patients of haemophilia were studied. Majority of patients were of haemophilia A (89\%). Most common age group was 6 - 15 years (49\%) and mean age was $19.02 \pm 12.58$ years. Most common age of onset was $<1$ year (62\%). Positive family history was present in $57 \%$ of cases. $52 \%$ patients had severe haemophilia. Most common presentation was haemarthrosis \& knee joint was the most common joint involved. APTT was prolonged in all cases.

\section{CONCLUSIONS}

Haemophiliacs are distributed worldwide and have heterogeneous presentation depending upon disease severity. Knowledge of the spectrum of presentation of haemophilia in the population helps in early diagnosis and management planning. Promotion of regular availability of factor concentrate, establishing comprehensive care center and positive public awareness along with good haematology laboratory will help in achieving outcome comparable to that of developed countries.

\section{KEY WORDS}

Haemophilia, Coagulation Profile, Musculoskeletal, Haemarthrosis
Corresponding Author: Dr. Praveen Sharma,

C/o. Pawan Automobiles, Near Kabir Ashram, Baroda Road, Sheopur-476337, Madhya Pradesh, India.

E-mail: drprash997@gmail.com

DOI: $10.14260 /$ jemds/2020/11

Financial or Other Competing Interests: None.

How to Cite This Article:

Nigam RK, Sharma P, Choudhary R, et al. Clinico-haematological profile of haemophilia in patients attending Gandhi medical college and associated Hamidia hospital Bhopal. J. Evolution Med. Dent. Sci. 2020;9(01):49-52, DOI:
Submission 19-08-2019,

Peer Review 21-12-2019,

Acceptance 27-12-2019,

Published 06-01-2020. 


\section{BACKGROUND}

The X-linked recessive inherited coagulation disorders, haemophilia A (Factor VIII deficiency) and haemophilia B (f actor IX deficiency) are the commonest forms of haemophilia.1,2 Incidence of haemophilia $A$ is 1 per 5,000 male birth and haemophilia B is 1 per 25,000 male birth. Deficiency of associated factors hamper the process of haemostasis and predisposes haemophiliacs to spontaneous or post traumatic bleeding. Factor deficient individuals have severe, moderate and mild forms of disease, defined by plasma factor levels of $<1 \%, 2-5 \%$, and $6-40 \%$ respectively. ${ }^{3}$ It is a sex-linked recessive disease and gene is located on Xq28. Point mutations of the gene are the most prevalent type of genetic defect seen in $90-95 \%$ of cases. Males are the sufferer and females are the carriers of this disease. Rare female homozygous cases are encountered. ${ }^{4}$

Haemarthrosis is the most common, as well as most physically, psychologically and economically exhausting manifestation of haemophilia. CNS bleeding is the most serious complication of haemophilia which may occur following a trauma or spontaneously. Immediate factor replacement is a must in this case. ${ }^{5}$ Activated partial thromboplastin time (APTT) is usually prolonged in patients with haemophilia (PwH). Factor VIII and factor IX assay are simple techniques, used for typing of severity of haemophilia and is done by two stage method, one stage method as well as micro-method. The one stage technique is used widely as it is simple to perform. ${ }^{6}$ Bleeding episodes in haemophiliacs are treated with factor replacement therapy. The approximate least desired factor level required to control bleeding episodes is $30 \%$ ( 0.3 units $/ \mathrm{ml}$ ), $50 \%$ (0.5 units $/ \mathrm{mi}$ ) and $80 \%-100 \%(0.8-1$ unit $/ \mathrm{ml})$ in case of mild bleeding, major bleeding and major surgery respectively. Units of factor VIII to be administered are "required rise in $\% \times$ weight in $\mathrm{kg} / 2$ " and units of factor IX to be administered are "required rise in $\% \times$ weight in $\mathrm{kg}^{\prime}{ }^{7}$

In developing nations including India, where haemophilia patients have limited access to prophylaxis and treatment, there is widespread suffering and from recurrent and prolonged joint bleeds. Morbidity from joint impairment increases markedly with advancement of age. Beside this, frequent use of blood and blood products as a cheaper substitute of factor concentrate increase the risk of acquiring transfusion transmitted infections in haemophiliacs. ${ }^{8}$ The world federation of haemophilia estimates that there are more than 4, 00, 000 individuals worldwide suffering from haemophilia. $80 \%$ of the haemophiliacs are in developing countries. In spite of this, in most of the developing countries, a very small amount of resources is spent on this disease. Under such circumstances, data collection for haemophilia remains very low priority. Scarcity of data in the developing countries makes it very difficult to represent the accurate situation regarding the epidemiology, clinical profile and management of these patients. Present study is designed for assessment of the clinical profile of haemophilia patients in central India and which type of clinical presentation must undergo coagulation profile testing to detect cases of haemophilia at the earliest to decrease morbidity and the mortality. Which can be helpful for the policy makers to improve services to detect and treat these patients. ${ }^{9-10}$

\section{METHODS}

This hospital based observational study was performed on all the patients (100) diagnosed as haemophilia referred to Hamidia Hospital from 1 ${ }^{\text {st }}$ March 2017 to 30th June 2018. Sample size was taken based on the convenience of the study. Patients with other bleeding disorders and those were on medication which can alter coagulation profile were excluded from the study. After taking written consent, all patients were subjected for clinical workup consist of a thorough history including relevant family history, general as well as systemic examination \& protocol wised laboratory tests were done. Diagnosis of haemophilia was made on the basis of relevant history, physical examination and laboratory investigations such as bleeding time (BT), Prothrombin time (PT), Activated Partial Thromboplastin Time (APTT), correction studies and whenever possible, specific coagulation factor assay. Beside of this, other haematological investigations like complete blood counts including peripheral blood smear were also carried out to see blood cell morphology, platelet count and morphology. The study was approved by the Ethical Committee.

\section{Statistical Analysis}

Descriptive analysis of qualitative variables was expressed in frequency and percentages. Statistical average was done by mean value and dispersion was measured by standard deviation.

\section{RESULTS}

This study was conducted in Gandhi Medical College \& associated Hamidia Hospital Bhopal. During our study period a total number of hundred patients were studied, out of which $89 \%$ patients were of haemophilia A \& 11\% patients were of haemophilia B with range of $82.21 \%-93.91 \%$ at $95 \%$ confidence interval). Most common age group was $6-15$ years which was $49 \%$ (39.42\% - 58.65\% at 95\% confidence interval). Mean age of patients was $19.02 \pm 12.58$ years with a age range of 1 - 65 years.

\begin{tabular}{|c|c|c|}
\hline Type of haemophilia & Number of Patients & Percentage \\
\hline Haemophilia A & 89 & $89 \%$ \\
\hline Haemophilia B & 11 & $11 \%$ \\
\hline Total & 100 & $100 \%$ \\
\hline
\end{tabular}

\begin{tabular}{|c|c|c|c|c|}
\hline Age (In Years) & Haemophilia A & Haemophilia B & Total & Percentage \\
\hline $0-5$ & 4 & 0 & 4 & $4 \%$ \\
\hline $6-15$ & 45 & 4 & 49 & $49 \%$ \\
\hline $16-30$ & 26 & 4 & 30 & $30 \%$ \\
\hline$>30$ & 14 & 3 & 17 & $17 \%$ \\
\hline Total & $\mathbf{8 9}$ & $\mathbf{1 1}$ & $\mathbf{1 0 0}$ & $\mathbf{1 0 0 \%}$ \\
\hline
\end{tabular}

Table 2. Age Wise Distribution of Haemophiliac Patients

Most common age of onset of first clinical manifestation was below 1 year. (41.35\% - 60.58\% at 95\% confidence interval) Mean age of onset was $2.44 \pm 2.77$ years and range was 1 month to 14 years. $57 \%$ patients had positive family history of haemophilia $(47.21 \%-62.27 \%$ at $95 \%$ confidence interval). Most common clinical presentation was haemarthrosis $(62.48 \%-79.90 \%$ at $95 \%$ confidence interval). 57\% had APTT above 80 seconds (47.21\% - 66.27\% 
at $95 \%$ confidence interval). APTT is increased in all patients. Patients with severe haemophilia usually had APTT above 80 seconds. Majority of patients (52\%) were severe haemophiliac (42.32\% - $61.54 \%$ at $95 \%$ confidence interval).

\begin{tabular}{|c|c|c|c|c|}
\hline $\begin{array}{c}\text { Family } \\
\text { History }\end{array}$ & Haemophilia A & Haemophilia B & Total & Percentage \\
\hline Present & 52 & 05 & 57 & $57 \%$ \\
\hline Absent & 37 & 06 & 43 & $43 \%$ \\
\hline Total & $\mathbf{8 9}$ & $\mathbf{1 1}$ & $\mathbf{1 0 0}$ & $\mathbf{1 0 0} \%$ \\
\hline \multicolumn{4}{|c|}{ Table 3. Distribution of Patients with Positive Family History } \\
\hline
\end{tabular}

\begin{tabular}{|c|c|c|c|c|}
\hline $\begin{array}{c}\text { Clinical } \\
\text { Presentation }\end{array}$ & Haemophilia A & Haemophilia B & Total & Percentage \\
\hline Haemarthrosis & 65 & 07 & 72 & $72 \%$ \\
\hline Intramuscular Bleed & 06 & 02 & 08 & $08 \%$ \\
\hline Gum bleed & 05 & 01 & 06 & $06 \%$ \\
\hline Subcutaneous bleed & 05 & 00 & 05 & $05 \%$ \\
\hline Epistaxis & 03 & 01 & 04 & $04 \%$ \\
\hline CNS bleed & 03 & 00 & 03 & $03 \%$ \\
\hline GI bleed & 01 & 00 & 01 & $01 \%$ \\
\hline $\begin{array}{c}\text { Genito-urinary } \\
\text { bleed }\end{array}$ & 01 & 00 & 01 & $01 \%$ \\
\hline Total & $\mathbf{8 9}$ & $\mathbf{1 1}$ & $\mathbf{1 0 0}$ & $\mathbf{1 0 0} \%$ \\
\hline Table 4. Clinical Presentations in Haemophiliac Patients \\
\hline
\end{tabular}

\begin{tabular}{|c|c|c|}
\hline APTT Range (in Seconds) & Number of Patients & Percentage \\
\hline $40-60$ & 09 & $09 \%$ \\
\hline $60-80$ & 34 & $34 \%$ \\
\hline$>80$ & 57 & $57 \%$ \\
\hline Total & $\mathbf{1 0 0}$ & $\mathbf{1 0 0} \%$ \\
\hline \multicolumn{2}{|c|}{ Table 5. Distribution of Patients According to APTT Range } \\
\hline
\end{tabular}

\begin{tabular}{|c|c|}
\hline Severity of haemophilia & Number of Patients \\
\hline Mild haemophilia & $26 \%$ \\
\hline Moderate haemophilia & $22 \%$ \\
\hline Severe haemophilia & $52 \%$ \\
\hline Total & $100 \%$ \\
\hline
\end{tabular}

\section{DISCUSSION}

Haemophilia A is more common than haemophilia B. Majority of the patients belong to haemophilia A type similar to study done by Uddin et al ${ }^{11}$ ( $80 \%$ haemophilia A), MA Karim et al ${ }^{12}$ (80\% haemophilia A), B Nikethan et al ${ }^{13}$ (81\% haemophilia A), R. K. Nigam et al $^{14}(88.19 \%$ haemophilia A), Saurabh Mishra et al ${ }^{15}$ (88.3\% haemophilia A), R Parthiban et al ${ }^{16}$ (82\% haemophilia A). Similar results were shown by other studies.

In present study, most common age range of haemophiliac patients was between 6-15 yrs (49\%). Similar age range is seen in study done by MM Uddin et al ${ }^{11}$ (6 - 15 yrs $=44 \%$ ) and R. K. Nigam et al ${ }^{14}(6-15$ yrs $=40.16 \%)$. Most common age group of patients in most of the studies was $<15$ yrs. The results correspond with other studies. ${ }^{17,18}$ The most common age of onset of clinical manifestation was below one year $51 \%$, which is corresponding with study done by Karim et al. $^{12}(<1 \mathrm{yr}=62 \%)$ and Payal et $\mathrm{al}^{19}(<1 \mathrm{yr}=51.78 \%)$. Patients with severe haemophilia had age of onset in their early life, while patients with moderate and mild haemophilia have late age of onset. In presents study, family history of haemophilia is present in $57 \%$ of cases. Which is corresponding to Saurabh Mishra ${ }^{15}$ et al (58\%) and MM Uddin $^{11}$ et al (60\%). Family history was positive in $70 \%$ of cases in study done by R. K. Nigam ${ }^{14}$ et al and $40 \%$ in study done by MA Karim ${ }^{12}$ et al. In most of the studies family history was positive in $40-70 \%$ of cases. These results are in accordance with other studies. ${ }^{20,21}$

In present study, in $52 \%$ patients bleeding starts spontaneously while in $48 \%$ patients bleeding starts following major or minor trauma. Similar results are seen in study done by R K Nigam ${ }^{14}$ et al (Spontaneous bleed - 57\%, traumatic bleed-33\%). While in study done by Shamoon ${ }^{22}$ et al percentage of spontaneous and traumatic bleeding in patients was $32 \%$ and $68 \%$ respectively. Low percentage of patients with spontaneous bleeding can be explained as many mild cases remain undiagnosed, and many others with severe diseases die early due to inadequate management. This is unlike the situation in the west where prophylactic replacement therapy turns young haemophiliacs to live almost normal life.

In severe haemophiliac patients, bleeding starts spontaneously and have prolong bleeding episode while in moderate haemophiliac patients, bleeding usually starts after minor or major trauma. In Mild haemophiliac patients, bleeding starts after major trauma. Most common clinical presentation in present study is haemarthrosis (72\%). Haemarthrosis as most common clinical manifestation is also seen in study done by Karim et al ${ }^{12}(82 \%)$, R.K. Nigam ${ }^{14}$ et al (76.7\%), Saurabh Mishra ${ }^{15}$ et al (64.96\%), Raina ${ }^{23}$ et al $(68.57 \%)$ and Shamoon ${ }^{22}$ et al (75\%). In present study, Knee joint is the most common involved joint. (52\%) which is corresponding to study done by MA Karim ${ }^{12}$ et al (Knee joint - 68\%), RK Nigam ${ }^{14}$ et al (Knee joint - 64.96\%), Saurabh Mishra ${ }^{15}$ et al (Knee joint - 57\%), Payal ${ }^{19}$ et al (Knee joint $67.8 \%$ ), Raina ${ }^{23}$ et al (Knee joint - 61.43\%), Shamoon et al ${ }^{22}$ (Knee joint - 60.1\%). In present study $52 \%$ patients have severe haemophilia, $22 \%$ patients have moderate haemophilia, $26 \%$ patients have mild haemophilia. Percentage of patients of mild, moderate and severe haemophilia in this study is corresponding to study done by Sadaria ${ }^{24}$ et al, Nikethan et al,13 Parthiban et al,16 Raina et al. $23,25-28$

In study done by R.K.Nigam ${ }^{14}$ et al, percentage of mild, moderate and severe was $32.38 \%, 36.22 \%$ and $31.4 \%$ respectively. The difference in percentage of mild, moderate and severe cases between present study and in study done by R. K. Nigam et $\mathrm{al}^{14}$ appears due to difference in study design. In study done by R. K. Nigam et al $^{14}$ all registered patients of haemophilia were studied which resulted in larger sample size and larger spectrum of cases. However present study was observational study where only the patients reporting during the study period were included. Patients with severe haemophilia reports frequently than patients with moderate and mild haemophilia.

\section{CONCLUSIONS}

Haemophiliacs are distributed worldwide and have heterogeneous presentation depending upon disease severity. Frequency and persistence of blood loss associated even with minimal trauma, especially in the presence of haemarthrosis, bruise and haematoma either spontaneous or traumatic in an otherwise normal child should alert the 
physician to investigate for haemophilia even in the absence of family history. Knowledge of the spectrum of presentation of haemophilia in the population helps in early diagnosis and management planning. Early recognition is important to establish correct treatment and to avoid unnecessary investigation. Most centers in developing countries including India do not have facility for factor concentration estimation; but clinically, we can assess severity of haemophilia with age of first bleed, type of bleed (like ICH) which should always be considered as severe, for treatment purposes. Factor replacement is the only treatment for haemophilia, ideally recombinant one that too preferably prophylactic. The specialty of transfusion medicine can be a core part of haemophilia care as it provides the laboratory services in the form of haemostasis, lab \& serology testing, testing for inhibitors, factor concentrates \& blood component support. Thus in future, we can treat PWH (Persons with Haemophilia) without pain \& disability by promoting regular availability of factor concentrate, prophylactic factor replacement, establishing comprehensive care center, regular training of medical and paramedical staff, and positive public awareness and a good haemostasis laboratory.

\section{REFERENCES}

[1] Mannucci PM, Tuddenham EG. The haemophilias-from royal genes to gene therap. $\mathrm{N}$ Engl J Med 2001;344(23):1773-9.

[2] Tuddenham EGD, Cooper DN. The molecular genetics of haemostasis and its inherited disorders. Oxford monographs in medical genetics. No. 25. Oxford, England: Oxford University Press 1994.

[3] Srivastava A. Haemophilia in developing countries - the challenge of detection and diagnosis. In: Sohail MT, Heijnen L. Comprehensive haemophilia case in developing countries. Lahore: Ferozsons 2001: p. 17-25.

[4] Singh T. Atlas and text of haematology. $3^{\text {rd }}$ edn. Avichal Publishing Co., 2014: p. 309.

[5] Roberts HR, Escobar M, White GC. haemophilia A and B. In: Lichtman MA, Beutler E, Kipps TJ, et al. eds. haematology. $7^{\text {th }}$ edn. New York: McGraw-Hill Publication 2006: p. 1867-86.

[6] Roberts HR. Coagulation disorders. In: Williams haematology. $5^{\text {th }}$ edn. Baltimore: Lippincott Williams \& Wilkins 1995: p. 1413-36.

[7] Mannucci PM. haemophilia: treatment options in the twenty first century. J Thromb Haemost 2003;1(7):134955.

[8] Bhattacharya DK. Haemophilia in the Indian Scenario. Int J Hum Genet 2006;6(1):33-9.

[9] History-of-Haemophilia. www.Haemophilia.in/index.php/Haemophilia

[10] https://www.wfh.org/en/page.aspx

[11] Uddin MM, Rahman MJ, Rahman MM, et al. Clinicopathological study on haemophilia: an analysis of 50 cases. J Bangladesh College of Physicians \& Surgeons 2006;24(2):50-3.
[12] Karim MA, Siddique R, Jamal C, et al. Clinical profile of haemophilia in children in a tertiary care hospital. Bangladesh J Child Health 2013;37(2):90-6.

[13] Nikethan B, Chaitanya V, Suresh H. ClinicoHaematological profile of haemophilia - at a tertiary care centre. Indian Journal of Basic and Applied Medical Research 2015;5(1):511-5.

[14] Nigam RK, Choudhary R, Malik R, et al. ClinicoHaematological study of haemophilia patients in Bhopal. Journal of Evolution of Medical and Dental Sciences 2014;3(11):2910-6.

[15] Mishra S, Kumar S, Panwar A, et al. A clinical profile of haemophilia patients and assessment of their quality of life in Western Uttar Pradesh, India: an observational study. Med J DY Patil Univ 2016;9:320-4.

[16] Parthiban R, Kaler AK, Sangeeta M, et al. A clinicopathological study of haemophilia in rural set up of Karnataka. British Journal of Medicine \& Medical Research 2015;6(10):948-55.

[17] Hazewinkel $\mathrm{MH}$, Hoogerwart JJ, Hesseling PB, et al. Haemophilia patients aged 0-18 years in the Western Cape. S Afr Med J 2003;93(10):793-6.

[18] Rahman M. Clinico-pathology study on haemorrhagic disorder (dissertation). Dhaka, Bangladesh College of Physicians and Surgeon 1998.

[19] Payal V, Sharma P, Goyal V, et al. Clinical profile of haemophilia patients in Jodhpur region. Asian J Transfus Sci 2016;10(1):101-4.

[20] Kitchens CS. Occult haemophilia. John Hopkins Med J 1980;147:255-9.

[21] Kar A, Potnis-Lele M. Descriptive epidemiology of haemophilia in Maharashtra, India. Haemophilia 2001;7(6):561-7.

[22] Rawand PS. Magnitude of arthropathy in patients with haemophilia: a single-center experience. Iraqi Journal of haematology 2017;6(2):78-83.

[23] Raina SK, Thaker BD, Arti Devi A, et al. Clinical profile of haemophilia patients in Jammu region. Sch J App Med Sci 2017;5(11B):4436-40.

[24] Sadaria TB, Goswami HM, Patel S. Study of laboratory parameters in haemophilia patients. Int J Cur Res Rev 2016;8(17):46-9.

[25] Blanchette VS, McCready M, Achonu C, et al. A survey of factor prophylaxis in boys with haemophilia followed in North American haemophilia treatment centers. haemophilia 2003;(9 Suppl 1):19-26.

[26] Ferreira AA, Bustamante-Teixeira MT, Leite ICG, et al. Clinical and functional evaluation of the joint status of haemophiliac adults at a Brazilian blood center. Revista Brasileira de haematologia e haemoterapia 2013; 35(1):23-8.

[27] ShanthalaDevi AM, Sitalakshmi S, Srikrishna A, et al. Profile of inherited bleeding disorder in a teaching hospital. Indian J haematol \& Blood Transf 1999;17:1618.

[28] Bick R. Vascular thromboHaemorrhagic disorders: hereditary and acquired. Clinical Application Thrombo haemost 2001;7(3):178-94. 